\title{
DIE PERSOONLIKHEIDSEIENSKAPPE EN BESTUURSPOTENSIAAL VAN BESTUURSGEMOTIVEERDE PERSONE
}

\author{
A S ENGELBRECHT
}

Departement Bedryfsielkunde
Universiteit van Stellenbosch

\begin{abstract}
The personality traits and managerial potential of managerial motivated persons: In the ligth of criticisms of the psychometric suitability of existing measures of managerial motivation a new scale, the Managerial Motivation Questionnaire (MMQ), was developed. This was done on the basis of a comprehensive study of the literature on managerial motivation and the role-motivation theory of Miner. The MMQ demonstrated adequate internal consistency. The aim of this study is to clarify the construct validity of the MMQ. Significant and positive correlations were found between managerial motivation, overall managerial potential, and nine managerial dimensions. The construct validity of the MMQ was further supported by correlations between sixteen personality traits and managerial motivation.
\end{abstract}

\section{OPSOMMING}

In die lig van kritiek teen die psigometriese geskiktheid van bestaande meetinstrumente van bestuursmotivering is 'n nuwe skaal, die Bestuursmotiveringsvraelys (BMV), ontwikkel. Dit is gedoen op grond van die konseptuele omlyning van bestuursmotivering en die rolmotiveringsteorie van Miner. Die BMV vertoon toereikende interne konsekwentheid. Die doel van hierdie studie is om die konstrukgeldigheid van die BMV verder op te klaar. Beduidend positiewe korrelasies is tussen bestuursmotivering, globale bestuurspotensiaal en nege bestuursdimensies gevind. Hierbenewens het die korrelasies tussen sestien persoonlikheidseienskappe en bestuursmotivering verdere ondersteunende bewyse gelewer van die konstrukgeldigheid van die BMV.

Literatuur oor leierskap in organisasies het veral in sommige van die meer onlangse takseer-sentrumnavorsing aan die lig gebring dat bestuursmotivering 'n belangrike voorspeller van bestuurspotensiaal en bestuursdoeltreffendheid is (Yukl, 1994; Stahl, 1986; Spangenberg, 1990; Miner, 1992). Ten einde die tekort aan bestuurders in die Suid-Afrikaanse ekonomie aan te vul behoort sterk bestuursgemotiveerde persone, ongeag geslag of ideologiese oortuigings, geïdentifiseer te word. Vir die wetenskaplike identifisering van bestuurspotensiaal behoort ' $n$ meetinstrument vir bestuursmotivering in keuringsbatterye en takseersentrums ingesluit te word (Engelbrecht en De Jager, 1991).

In terme van die bestuursrol-motiveringsteorie van Miner (1978; 1992, p.64) kan daar 'n positiewe verband tussen bestuursmotivering en bestuurspotensiaal gepostuleer word. Een van die beste voorbeelde van takseersentrumnavorsing is die longitudinale studie uitgevoer by AT\&T deur Bray, Campbell en Grant in 1974 (Miner, 1978). Die oortuigende bevinding van hierdie studie is dat suksesvolle bestuurders beskik oor ' $n$ hoë mate van administratiewe en interpersoonlike vaardighede, intellektuele vermoë, stabiliteit in prestasie, werksmotivering en loopbaanoriëntasie, en 'n lae afhanklikheid van ander openbaar. Miner (1978) beweer dat hierdie veranderlikes konseptueel redelik ooreenstem met die mededingendheid, selfhandhawing en roetine administratiewe funksieskomponente van die rolmotiveringsteorie. In Tabel 1 verskyn die interpretasies van hierdie dimensies van bestuursmotivering.

Daar kan dus verwag word dat bestuursmotivering positief met die bestuursdimensies van takseersentrums behoort te korreleer. Daar kon egter geen studie in die literatuur gevind word waarin hierdie betrokke verband empiries ondersoek is nie. Navorsing op hierdie gebied sal dus betekenisvol tot die geldigheid van die rolmotiveringsteorie kan bydra.

Die belangrike rol wat persoonlikheidseienskappe in die bepaling van bestuur- en organisatoriese sukses in organisasies speel, word deur verskeie navorsers beklemtoon (De Bod en Slivinsky, 1983; Berman en Miner, 1985). Een van die kon-

Versoeke vir afdrukke moet gerig word aan A S Engelbrecht, Departement Bedryfsielkunde. Universiteit van Stellenbosch, Privaatsak X 5018, Stellenbosch 7599.
TABEL 1

DIMENSIES VAN BESTUURSMOTIVERING

\begin{tabular}{ll}
\hline DIMENSIE & INTERPRETASIE \\
\hline $\begin{array}{l}\text { Positiewe houding } \\
\text { teenoor gesagsfigure }\end{array}$ & $\begin{array}{l}\text { 'n Drang om aan bestuursrol- } \\
\text { vereistes in terme van positiewe } \\
\text { verhoudings met meerderes te } \\
\text { voldoen. }\end{array}$ \\
Kompetisiedrang & $\begin{array}{l}\text { 'n Drang om in kompetisie met } \\
\text { gelykes betreffende beroeps- of } \\
\text { werksverwante aktiwiteite } \\
\text { betrokke te raak en gevolglik te } \\
\text { voldoen aan bestuursrolvereistes } \\
\text { in hierdie verband. }\end{array}$
\end{tabular}

Selfhandhawingsdrang

'n Drang om op 'n aktiewe en selfhandhawende wyse op te tree en gevolglik aan bestuursrolvereistes te voldoen.

Magsdrang

Behoefte aan onderskeidende groepsrol

'n Drang om andere te vertel wat om te doen en om sanksies te gebruik om andere te beïnvloed en gevolglik 'n kapasiteit te toon om bestuursrolvereistes in verhoudings met ondergeskiktes te vervul.

'n Drang om 'n onderskeidende posisie van ' $n$ unieke en hoogs sigbare aard aan te neem op 'n wyse wat rolooreenstemmend aan die bestuurspos is.

Positiewe houding teenoor administratiewe take

'n Drang om te voldoen aan bestuursrolvereistes betreffende aktiwiteite wat dikwels met bestuurswerk van 'n dag-tot-dag administratiewe aard geassosieer word.

(Aangepas uit Engelbrecht en De Jager, 1991, p. 19)

sekwente patrone wat uit hierdie studies na vore kom, weer spieël 'n strewe na mag en dominansie, gekoppel met gunstige houdings teenoor gesagsfigure, ' $n$ neiging om jouself te laat geld en 'n voorkeur vir administratiewe werk. Hierdie 
patroon van eienskappe stem in 'n groot mate ooreen met die veranderlikes van die rolmotiveringsteorie van Miner (Berman en Miner, 1985). Hierdie patroon word ook bevestig deur McClelland (McClelland, 1987; Stahl, 1986) se bestuursmotiveringsmodelle waarin die prestasiemotief, en veral die magsmotief, 'n dominante rol speel.

In 'n studie met 101 personeelbestuurders het Miner (1978, p.755) beduidende korrelasies gevind tussen die totale Miner Sentence Completion Scale (MSCS)-telling en beslistheid ( $r=$ $0,35, p<0,01)$, toesighoudingsvermoë $(r=0,26, p<0,01)$, selfvertroue $(r=0,24, p<0,05)$, behoefte aan beroepsprestasie $(r=0,17, p<0,10)$ en sekuriteitsbehoefte $(r=-0,26, p<0,01)$; soos deur middel van Ghiselli se Self-Description Inventory (SDI) gemeet. Coetsee (1973) het die SDI ook op SuidAfrikaanse bestuurders $(\mathrm{N}=313)$ toegepas en gevind dat hierdie persoonlike eienskappe beduidend met bestuursukses verband hou. Dit word verder bevestig deur die profiel van die suksesvolle bestuurder wat Coetsee (1976, p.15) op grond van 'n vergelyking van die resultate van vier studies saamgestel het.

Miner (1977, p.62) kon egter by 'n bestuursgroep geen beduidende verband vind tussen die magsbehoefte van die SDI en die totale telling van die MSCS of die magsdrang-subskaal nie. Hierdie onverwagte bevinding kan moontlik verklaar word deurdat Ghiselli se beskouing van die magsbehoefte meer ooreenstem met McClelland (1975) se verpersoonlikte magsoriëntasie. Hierteenoor stem Miner se konstruk van bestuursmotivering en magsdrang weer meer ooreen met McClelland se gesosialiseerde magsoriëntasie (Miner, 1978).

Livingston (Engelbrecht, 1989, p.195) sonder die behoefte om te bestuur ("need to manage") as een van die tipiese kenmerke van effektiewe bestuurders uit. Livingston omskryf hierdie bestuurseienskap as die behoefte om die prestasie van ander te beïnvloed en om werklik tevredenheid daaruit te put. Dit blyk dat hierdie siening van Livingston met Miner en McClelland se beskouing oor die eienskap bestuursmotivering in verband gebring kan word.

Verder het Roebuck (Miner, 1978, p.756) 'n aantal voorspellers van bestuursukses uit verskeie studies geïdentifiseer. Volgens Roebuck is die mees konsekwente voorspellers van 'n motiverings- of persoonlikheidsaard sosialiteit, algemene aktiwiteit, sosiale leierskap, dominansie, toleransie en selfvertroue-skale van die Guilford-Martin Personality Inventories. Hierdie eienskappe het heelwat konseptuele ooreenkoms met die konstrukte van die rolmotiveringsteorie (Miner, 1978).

Die persoonlikheidsvraelys wat in Suid-Afrika die meeste gebruik word om bestuurspotensiaal te voorspel is waarskynlik die Sestien-Persoonlikheidsfaktorvraelys (16-PF) (Augustyn en Van Wyk, 1988; Cattell, Eber en Taksuoka, 1980). In Tabel 2 word die sestien primêre persoonlikheidsfaktore, wat deur die 16-PF gemeet word, aangedui.

'n Lys van enkele meer beskrywende terme (Madge en Du Toit, 1982), wat die resultate van die toets meer interpreteerbaar maak, verskyn ook in Tabel 2 . Ten einde die 16-PF-faktore verder op te klaar word die korrelate wat tussen die $16-\mathrm{PF}$ en ander erkende persoonlikheidsvraelyste gevind is ook vermeld. Op grond van ' $n$ literatuurstudie asook ' $n$ inhoudsanalise van die dimensies van die 16-PF en bestuursmotivering (Engelbrecht, 1991; Kyk ook Tabelle 1 en 2) blyk dit dat daar ' $n$ beduidend positiewe verband tussen bestuursmotivering en faktore A, E, F, G, H, N, Q2 en Q3 gepostuleer kan word. Hierteenoor behoort bestuursmotivering beduidend negatief met faktore $\mathrm{M}, \mathrm{O}$ en Q4 te korreleer. Hierbenewens behoort faktore $B, C, I, L$ en $Q 1$ geen beduidende verband met bestuursmotivering te toon nie.

Dit blyk uit die literatuur dat relatief min empiriese navorsing fokus op persoonlikheidseienskappe wat bestuursmotivering beïnloed. Uit enkele studies wat wel gedoen is, blyk dit tog dat bestuursmotivering positief met bestuursrelevante persoonlikheidseienskappe korreleer (Miner, 1977, p.62; Miner, 1978).
TABEL 2

GEPOSTULEERDE VERBAND TUSSEN BESTUURSMOTIVERING EN DIE PERSOONLIKHEIDSDIMENSIES VAN DIE 16-PF

\begin{tabular}{|c|c|c|c|}
\hline 16-PF-FAKTORE & $\begin{array}{l}\text { BESKRYWENDE } \\
\text { TERME } \\
\text { (MADGE \& DU } \\
\text { TOIT, 1982) }\end{array}$ & $\begin{array}{l}\text { PERSOONLIK- } \\
\text { HEIDS-KOR- } \\
\text { RELATE (KRUG, } \\
\text { 1983) }\end{array}$ & $\begin{array}{l}\text { GEPOSTULEER- } \\
\text { DE r MET } \\
\text { BESTUURS- } \\
\text { MOTIVERING }\end{array}$ \\
\hline +A: Hartlikheid & $\begin{array}{l}\text { Na-buite-lewend, } \\
\text { Deelnemend } \\
\text { Goedhartig } \\
\text { Sorgeloos }\end{array}$ & $\begin{array}{l}\text { Selfvertoning } \\
\text { Ontvanklikheid } \\
\text { Sosialiteit } \\
\text { Affiliasie }\end{array}$ & Positief \\
\hline $\begin{array}{l}+\mathrm{B} \text { : Hoë intel- } \\
\text { ligensie }\end{array}$ & Skrander & - & Geen \\
\hline $\begin{array}{l}+\mathrm{C}: \text { Hoër } \\
\text { egosterkte }\end{array}$ & $\begin{array}{l}\text { Emosioneel } \\
\text { stabiel, volwasse, } \\
\text { kalm }\end{array}$ & $\begin{array}{l}\text { Gevoel van geluk } \\
\text { en tevredenheid }\end{array}$ & Geen \\
\hline$+\mathrm{E}:$ Dominansie & $\begin{array}{l}\text { Selfgeldend } \\
\text { Mededingend }\end{array}$ & $\begin{array}{l}\text { Statusbewus } \\
\text { Selfgerigtheid } \\
\text { Ambisieus }\end{array}$ & Positief \\
\hline$+F$ : Sorgvryheid & Geesdriftig & $\begin{array}{l}\text { Selfvertoning } \\
\text { Sosialiteit }\end{array}$ & Positief \\
\hline $\begin{array}{l}\text { +G: Hoër super- } \\
\text { egosterkte }\end{array}$ & $\begin{array}{l}\text { Konsensieus } \\
\text { volhardend }\end{array}$ & Sistematies & Positief \\
\hline $\begin{array}{l}+\mathrm{H} \text { : Sosiale } \\
\text { vrypostigheid }\end{array}$ & Vrymoedig & $\begin{array}{l}\text { Dominansie } \\
\text { Selfvertoning } \\
\text { Selfvertroue } \\
\text { Sosialiteit } \\
\text { Entoesiasme }\end{array}$ & Positief \\
\hline $\begin{array}{l}\text { +1: Emosionele } \\
\text { gevoeligheid }\end{array}$ & Sensitief & Versorging & Geen \\
\hline $\begin{array}{l}+\mathrm{L}: \text { Agterdog- } \\
\text { tigheid }\end{array}$ & Wantrouig & Aggressie & Geen \\
\hline -M: Prakties & $\begin{array}{l}\text { Met albei voete } \\
\text { op die aarde }\end{array}$ & $\begin{array}{l}\text { Sistematies } \\
\text { Ordening }\end{array}$ & Negatief \\
\hline $\begin{array}{l}\text { +N: Skerpsin- } \\
\text { nigheid }\end{array}$ & Wêreldwys & Selfbeheer & Positief \\
\hline $\begin{array}{l}\text {-O: Selfver- } \\
\text { sekerdheid }\end{array}$ & $\begin{array}{l}\text { Selfvoldaan } \\
\text { Bedaard }\end{array}$ & $\begin{array}{l}\text { Statusbewus } \\
\text { Sosiale teen- } \\
\text { woordigheid }\end{array}$ & Negatief \\
\hline $\begin{array}{l}\text { +Q1: Radika- } \\
\text { lisme }\end{array}$ & $\begin{array}{l}\text { Vrydenkend } \\
\text { Ondersoekend }\end{array}$ & $\begin{array}{l}\text { Outonomie } \\
\text { Aggressie }\end{array}$ & Geen \\
\hline $\begin{array}{l}+ \text { Q2: Self- } \\
\text { genoegsaamheid }\end{array}$ & $\begin{array}{l}\text { Vindingryk } \\
\text { Verkies om self } \\
\text { besluite te neem }\end{array}$ & - & Positief \\
\hline $\begin{array}{l}\text { +Q3: Sterk self- } \\
\text { sentiment }\end{array}$ & $\begin{array}{l}\text { Selfbeheersd } \\
\text { Sosiaal korrek }\end{array}$ & $\begin{array}{l}\text { Persoonlike } \\
\text { aanpassing } \\
\text { Ordening } \\
\text { Sistematies }\end{array}$ & Positief \\
\hline $\begin{array}{l}\text {-Q4: Lae } \\
\text { drangpeil }\end{array}$ & $\begin{array}{l}\text { Ontspanne } \\
\text { Rustig }\end{array}$ & $\begin{array}{l}\text { Bedaard } \\
\text { Goeie indruk } \\
\text { Selfbeheer } \\
\text { Toleransie }\end{array}$ & Negatief \\
\hline
\end{tabular}

Die bestuursmotiveringskonstruk is in wese ' $n$ eienskapsbenadering tot bestuursdoeltreffendheid (Yukl, 1994). Verder kan die rolteorie van bestuursmotivering van Miner as ' $n$ inhoudsteorie van motivering geklassifiseer word. Die hoofkritiek teen die rolmotiveringsteorie is gevolglik dat dit nie ' $n$ goeie verklaring vir die verband tussen bestuursmotivering en bestuursgedrag bied nie, en dat dit nie die rol van situasionele veranderlikes in bestuursmotivering uitspel nie (Bartol en Martin, 1987).

Ten einde 'n goeie verklaring te probeer gee van die waarskynlike verwantskappe tussen bestuursmotiewe, -potensiaal, doeltreffendheid en bestuurstevredenheid het Engelbrecht 
(1989, p.204) 'n sintetiese model uit die motiverings- en leierskapsliteratuur ontwikkel. Uit hierdie geïntegreerde bestuursmotiveringsmodel kan die afleiding gemaak word dat die verband tussen bestuursmotiewe en bestuursdoeltreffendheid waarskynlik onder andere deur bestuurspotensiaal en persoonlikheidseienskappe van bestuurders gemodereer word.

In die literatuur kon geen Suid-Afrikaanse studie gevind word waarin bestuursmotivering, soos deur Miner of McClelland geoperasionaliseer, empiries met bestuurspotensiaal of met persoonlikheidseienskappe van bestuurders verband hou nie. Daar blyk dus ' $n$ leemte te bestaan aan navorsing op hierdie terrein in die Suid-Afrikaanse konteks.

Die navorsingsprobleem van hierdie studie kan dus soos volg gestel word: In watter mate word bestuursmotivering deur persoonlikheidseienskappe en bestuurspotensiaal beïnvloed? Die doel van hierdie studie is dan om die verwantskappe tussen hierdie drie veranderlikes te ondersoek.

\section{METODE}

\section{Hipoteses}

Na aanleiding van die probleemstelling, die doelstelling van die ondersoek en die literatuurstudie word die volgende hipoteses gestel:

Hipotese 1: Daar bestaan 'n beduidend positiewe verband tussen bestuursmotivering en die volgende aspekte van bestuurspotensiaal:

(a) Globale bestuurspotensiaal;

(b) Bestuursareas;

(c) Bestuursdimensies.

Hipotese 2: Daar bestaan ' $\mathrm{n}$ beduidend positiewe verband tussen bestuursmotivering en die volgende persoonlikheidseienskappe:

(a) Faktor A (terughoudendheid teenoor hartlikheid)

(b) Faktor E (onderdanigheid teenoor dominansie)

(c) Faktor F (soberheid teenoor sorgvryheid)

(d) Faktor G (laer teenoor hoër superegosterkte)

(e) Faktor $\mathrm{H}$ (skugterheid teenoor sosiale vrypostigheid)

(f) Faktor $\mathrm{N}$ (naïwiteit teenoor skerpsinnigheid)

(g) Faktor Q2 (groepafhanklikheid teenoor selfgenoegsaamheid)

(h) Faktor Q3 (gebrekkige teenoor sterk selfsentiment)

Hipotese 3: Daar bestaan ' $n$ beduidend negatiewe verband tussen bestuursmotivering en die volgende persoonlikheidseienskappe:

(a) Faktor M (prakties teenoor onkonvensioneel)

(b) Faktor O (selfversekerdheid teenoor geneigdheid tot skuldgevoelens)

(c) Faktor Q4 (lae teenoor hoë drangpeil)

Hipotese 4: Daar bestaan geen beduidende verband tussen bestuursmotivering en die volgende persoonlikheidseienskappe nie:

(a) Faktor B (lae teenoor hoë intelligensie)

(b) Faktor C (egoswakheid teenoor hoër egosterkte)

(c) Faktor I (ontoegeeflikheid teenoor emosionele gevoeligheid)

(d) Faktor L (gevoel van geborgenheid teenoor agterdogtigheid)

(e) Faktor Q1 (konserwatisme teenoor radikalisme)

\section{Meetinstrumente}

Die meting van bestuursmotivering

Die Bestuursmotiveringsvraelys (BMV) (Engelbrecht, 1991) is gebruik om bestuursmotivering te meet. Hierdie meetinstrument bestaan uit ses subskale wat onderskeidelik die ses dimensies van bestuursmotivering meet.

Engelbrecht (1991, p.12) kon geen beduidende verband vind tussen die totale BMV-telling en die totale telling van die Marlowe-Crowne Sosiale Wenslikheidskaal (Crowne en Marlowe, 1960) nie $(\mathrm{N}=103)$.
Wat die interne konsekwentheid van die BMV betref, is ' $n$ hoë alfa-koëffisiënt van 0,91 ten opsigte van die totaaltelling verkry $(\mathrm{N}=535)$ (Engelbrecht, 1991, p.12). Die gemiddelde van 0,80 ten opsigte van die ses subskale is ook redelik bevredigend.

Engelbrecht (1991, p.10) het verder met behulp van bevestigende faktorontledings daarin geslaag om items te identifiseer wat almal relatief suiwer en betroubare faktore in die sub-skale van die BMV meet $(\mathrm{N}=360)$.

Op grond van sosiale wenslikheids- en semantiese beoordeling, item- en faktor-ontledings het Engelbrecht (1991) dus daarin geslaag om 'n BMV te ontwikkel wat redelik vry van sosiale wenslikheid is, bevredigende interne konsekwentheid toon, en waarvan die items in die subskale almal relatief suiwer metings van die geisoleerde faktore is.

Die meting van bestuurspotensiaal

Daar is besluit om die takseersentrum van ' $n$ groot SuidAfrikaanse vervoeronderneming te gebruik om die 13 dimensies van bestuurspotensiaal te meet. In 'n geldigheidstudie van hierdie takseersentrum het Britz (1987, p.23) gevind dat die sentrumtotaaltelling beduidend met vyf kriteria van bestuursukses korreleer $(r=0,56$ tot $0,63, p<0,001)$. Britz (1987) het ook meervoudige korrelasies tussen die 13 bestuursdimensies en die vyf afsonderlike kriteria van bestuursukses bereken en korrelasiekoëffisiënte gevind wat van 0,59 tot 0,77 gevarieer het.

In die lig van hierdie goeie geldigheidsresultate en die deeglike ontwerp en professionele wyse waarop die takseersentrum van die betrokke vervoeronderneming bedryf word, is hierdie takseersentrum met vertroue aanvaar as 'n meetinstrument van bestuurspotensiaal.

\section{Die meting van persoonlikheidseienskappe}

In hierdie studie is die persoonlikheidseienskappe van die bestuursteekproef met behulp van die Sestien-Persoonlikheidsfaktorvraelys (16-PF) gemeet (Cattell et al, 1980). Op grond van intensiewe navorsing en met behulp van ' $n$ omvattende proses van faktorontleding is die sestien belangrikste persoonlikheideienskappe geïdentifiseer (Cattell, et al., 1980).

Wat die betroubaarheid van die 16-PF betref, het Cattell, et al. (1980, p.31) verdeelde-helfte betroubaarheidskoëffisiënte vir die verskillende faktore bereken en dit wissel van 0,71 tot 0,93 . Cattell, et al. rapporteer ook hertoetsbetroubaarheid, met 'n tydsverloop van twee maande, waar die koëffisiënte varieer tussen 0,63 en 0,88 .

Cattell, et al. (1980) het verder gevind dat geldigheidskoëffisiënte (korrelasies met suiwer 16-PF-faktore) tussen 0,41 en 0,92 wissel (Cattell, et al., p.36).

Verskeie navorsers (Krug, 1983, pp.5-10) het verder konvergente en diskriminante geldigheidsgegewens verskaf deur die vergelyking van die 16-PF skale met dié van konseptueel ooreenstemmende en verskillende skale van ander erkende persoonlikheidsvraelyste. In die studie van Augustyn en Van Wyk (1988) word ook aanduidings van samevallende geldigheid van die 16-PF gelewer.

Die 16-PF is deur die RGN vir die Suid-Afrikaanse toestande aangepas en gestandaardiseer (Maas, 1980, p.46), en daar is besluit om hierdie aangepaste vraelys te gebruik.

\section{Steekproef}

Ten einde die spesifieke hipoteses van hierdie studie te toets, is die meetinstrumente toegepas op 'n steekproef van middelbestuurders by twee groot organisasies, naamlik ' $n$ vervoeronderneming ( $N=126$ ) en 'n lewensversekeringsmaatskappy $(\mathrm{N}=67)$. Die rasionaal vir die keuse van die grootste lewensversekeringsmaatskappy en die grootste vervoeronderneming in Suid-Afrika is dat hierdie ondernemings as burokratiese organisasies getipeer kan word. Hulle organisasie- 
strukture word gekenmerk deur ' $n$ hoë mate van rolspesialisasie, sentralisasie van gesag, formalisasie en 'n nou spanwydte van kontrole (Weber in Miner, 1992). Op grond hiervan kan beweer word dat die voorafgaande organisasies binne die domein van die rolteorie van bestuursmotivering val (Miner, 1978).

\section{Statistiese ontledings}

Vir die statistiese ontledings van die ingesamelde gegewens is daar van Pearson se produk-momentkorrelasiekoëffisiënt en die SPSS-X rekenaarpakket gebruik gemaak.

\section{RESULTATE}

Die verband tussen bestuursmotivering en bestuurspotensiaal

Die resultate oor die verband tussen bestuursmotivering en bestuurspotensiaal word in Tabel 3 uiteengesit.

TABEL 3

KORRELASIES TUSSEN BESTUURSMOTIVERING EN DIE BESTUURSDIMENSIES VAN DIE TAKSEERSENTRUM $(N=126)$

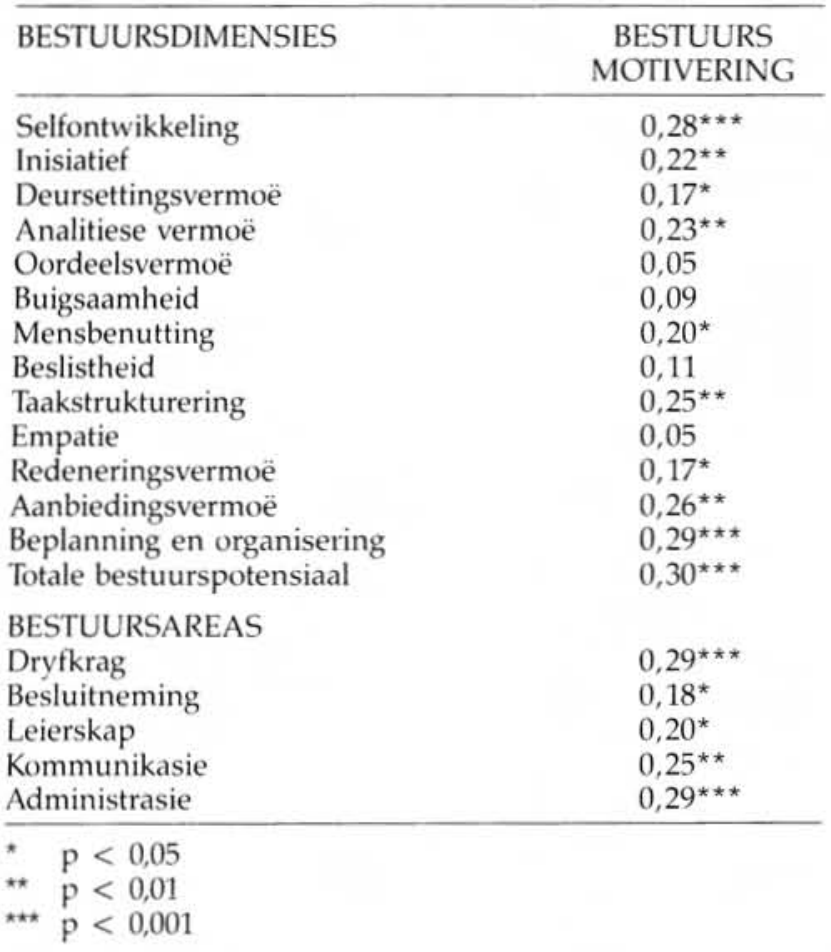

Dit blyk uit Tabel 3 dat bestuursmotivering beduidend positief korreleer met globale bestuurspotensiaal en vyf bestuursareas, naamlik dryfkrag, besluitneming, leierskap, kommunikasieen administratiewe vaardighede. Hipotese 1(a) en (b), naamlik dat daar ' $n$ beduidend positiewe verband tussen bestuursmotivering en globale bestuurspotensiaal en bestuursareas bestaan, word dus bevestig. Daar is ook ' $n$ beduidend positiewe verband gevind tussen bestuursmotivering en selfontwikkeling, inisiatief, deursettingsvermoë, analitiese vermoë, mensbenutting, taakstrukturering, redeneringsvermoë, aanbiedingsvermoë, beplanning en organisering. In teenstelling hiermee kon geen beduidende verwantskappe tussen bestuursmotivering en onderskeidelik oordeelsvermoë, empatie, buigsaamheid en beslistheid gevind word nie. Hierdie resultate het dus hipotese $1(\mathrm{c})$, te wete dat daar 'n beduidend positiewe verband tussen globale bestuursmotivering en hierdie bestuursdimensies bestaan, slegs gedeeltelik ondersteun.

Die gebrek aan ' $n$ beduidend positiewe verband tussen bestuursmotivering en buigsaamheid asook bestuursmotivering en beslistheid is waarskynlik daaraan toe te skryf aan ' $n$ te hoë mate van buigsaamheid en beslistheid beperkend op bestuursdoeltreffendheid kan inwerk. Britz (1987) kon ook nie ' $n$ beduidende verband tussen buigsaamheid en bestuursukses vind nie. Die gebrek aan 'n positiewe verband tussen bestuursmotivering en buigsaamheid en beslistheid kan waarskynlik ook toegeskryf word aan die sterk beduidend negatief skewe verspreiding van buigsaamheids- en beslistheidstellings. Uit die onbeduidende verband tussen bestuursmotivering en oordeelsvermoë en empatie kan die afleiding gemaak word dat hierdie twee bestuursdimensies en bestuursmotivering mekaar nie onderling beïnvloed nie.

Die verband tussen persoonlikheidseienskappe en bestuursmotivering

Die korrelasies tussen die 16-PF-faktore en bestuursmotivering word in Tabel 4 aangetoon.

\section{TABEL 4}

\section{KORRELASIES TUSSEN BESTUURSMOTIVERING EN DIE PERSOONLIKHEIDSDIMENSIES VAN DIE $16-\mathrm{PF}(\mathrm{N}=67)$}

16-PF-FAKTORE

16-PF-FAKTORE BESTUURSMOTIVERING

\begin{tabular}{|c|c|c|}
\hline A: & Terughoudendheid - Hartlikheid & $0,30^{\star \star}$ \\
\hline B: & Lae - Hoë intelligensie & $-0,06$ \\
\hline C: & Egoswakheid - Hoër egosterkte & 0,03 \\
\hline E: & Onderdanigheid - Dominansie & $0,49^{\star \star \star *}$ \\
\hline $\mathrm{F}:$ & Soberheid - Sorgvryheid & $0,36^{\star \star \star *}$ \\
\hline G: & Laer - Hoër superegosterkte & 0,19 \\
\hline $\begin{array}{l}\mathrm{H}: \\
\mathrm{I}:\end{array}$ & $\begin{array}{l}\text { Skugterheid - Sosiale vrypostigheid } \\
\text { Ontoegeeflikheid - Emosionele }\end{array}$ & $0,48^{\star \star *}$ \\
\hline & Gevoeligheid & $-0,06$ \\
\hline L: & $\begin{array}{l}\text { Gevoel van geborgenheid - agter- } \\
\text { dogtigheid }\end{array}$ & 0,13 \\
\hline M: & Prakties - onkonvensioneel & $-0,27^{\star}$ \\
\hline$N:$ & Naïwiteit - skerpsinnigheid & $0,23^{*}$ \\
\hline O: & $\begin{array}{l}\text { Selfversekerdheid - Skuld- } \\
\text { geneigdheid }\end{array}$ & $-0,43^{\star \star \star}$ \\
\hline Q1: & Konserwatisme - radikalisme & 0,03 \\
\hline 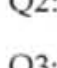 & $\begin{array}{l}\text { Groepafhanklikheid - selfgenoeg- } \\
\text { saamheid }\end{array}$ & $-0,22^{\star}$ \\
\hline Q3: & $\begin{array}{l}\text { Gebrekkige selfsentiment - sterk } \\
\text { selfsentiment }\end{array}$ & 0,18 \\
\hline Q4: & Lae - hoë drangpeil & $-0,20^{\star}$ \\
\hline $\begin{array}{l}* \star \\
\star \star *\end{array}$ & $\begin{array}{l}p<0,05 \\
p<0,01 \\
p<0,001\end{array}$ & \\
\hline
\end{tabular}

Dit is duidelik uit Tabel 4 dat bestuursmotivering beduidend positief korreleer met onderskeidelik faktor A (terughoudendheid teenoor hartlikheid), faktor E (onderdanigheid teenoor dominansie), faktor $F$ (soberheid teenoor sorgvryheid), faktor $\mathrm{H}$ (skugterheid teenoor sosiale vrypostigheid) en faktor $\mathrm{N}$ (naiwiteit teenoor skerpsinnigheid). Hierdie resultate bevestig dus hipotese 2 (a), (b), (c), (e) en (f), naamlik dat daar ' $n$ beduidend positiewe verband tussen faktore A, E, F, H en N, en bestuursmotivering bestaan.

In teenstelling hiermee is daar beduidend negatiewe korrelasies gevind tussen bestuursmotivering en onderskeidelik faktor $\mathrm{M}$ (prakties teenoor onkonvensioneel), faktor O (selfversekerdheid teenoor geneigdheid tot skuldgevoelens), faktor Q2 (groepafhanklikheid teenoor selfgenoegsaamheid) en faktor Q4 (lae teenoor hoë drangpeil). Dit impliseer dat hipotese 3 (a), (b) en (c) wat beduidend negatiewe korrelasies tussen bestuursmotivering en faktore $\mathrm{M}, \mathrm{O}$ en Q4 postuleer, vok bevestig word. Daar kon egter nie bevestiging gekry word vir hipotese $2(\mathrm{~g})$ nie, naamlik dat daar ' $\mathrm{n}$ beduidend positiewe korrelasie tussen bestuursmotivering en faktor Q2 bestaan. Die onverwagte beduidend negatiewe verband tussen bestuursmotivering en faktor Q2 kan waarskynlik daaraan toegeskryf word dat 'n persoon van 'n groep afhanklik is vir die bevrediging van sommige van sy bestuursmotiewe, soos die behoefte aan ' $n$ onderskeidende groepsrol.

Daar kon verder geen beduidende korrelasies verkry word tussen bestuursmotivering en onderskeidelik faktor B (laer teenoor hoë intelligensie), faktor C (ego-swakheid teenoor hoër egosterkte), faktor $\mathrm{G}$ (lae teenoor hoër superegosterkte), 
faktor I (ontoegeeflikheid teenoor emosionele gevoeligheid), faktor L (gevoel van geborgenheid teenoor agterdogtigheid), Q1 (konserwatisme teenoor radikalisme) en Q3 (gebrekkige teenoor sterk selfsentiment) nie. hierdie bevindings ondersteun dus hipoteses 4 (a) tot (e), naamlik dat daar geen beduidende verband tussen faktor B, C, I, L en Q1, en bestuursmotivering bestaan nie. Hipoteses 2 (d) en (h), naamlik dat daar ' $n$ beduidend positiewe verband tussen faktore $\mathrm{G}$ en $\mathrm{Q} 3$, en bestuursmotivering bestaan, is egter nie bevestig nie. Hierdie resultate ondersteun 13 van die 16 hipoteses, afgelei van die rolteorie van bestuursmotivering.

Die verkreë onbeduidende verband tussen bestuursmotivering en faktor $\mathrm{G}$ dui daarop dat persone wat volhardend, konsensieus, moralisties en bedaard is, nie noodwendig ' $n$ hoë motivering om te bestuur het nie. Die gebrek aan ' $n$ beduidend positiewe verband tussen bestuursmotivering en faktor Q3 dui verder daarop dat persone wat selfbeheersd, 'n streng wilskrag en 'n goeie selfbeeld het nie noodwendig persone met hoë bestuursmotivering is nie.

\section{BESPREKING VAN RESULTATE EN GEVOLGTREKKING}

Die algemene doel van hierdie studie is om die verwantskappe tussen persoonlikheid, bestuurspotensiaal en bestuursmotivering verder op te klaar. Ten einde hierdie doel te verwesenlik is daar van ' $n$ ex post facto korrelatiewe studie gebruik gemaak.

Beduidend positiewe korrelasies is gevind tussen bestuursmotivering, globale bestuurspotensiaal en nege bestuursdimensies. Bestuursmotivering toon verder beduidend positiewe korrelasies met vyf bestuursareas, naamlik dryfkrag, besluitneming, leierskap, kommunikasievaardighede en administratiewe vaardighede.

Daar kan dus tot die slotsom geraak word dat die korrelering van die BMV met die bestuursdimensies van die betrokke takseersentrum besonder bevredigende resultate opgelewer het wat die konstrukgeldigheid van die BMV sterk ondersteun. Dit blyk dus dat bestuursmotivering ' $n$ belangrike faset van bestuurspotensiaal uitmaak. Alhoewel geen ander studie oor die verband tussen bestuursmotivering en bestuurspotensiaal gevind kon word waarin bestuurspotensiaal met behulp van 'n takseersentrum gemeet is nie, ondersteun hierdie resultate die positiewe verband tussen hierdie twee veranderlikes wat in ander studies gevind is (Miner, 1978).

Dit blyk verder uit die resultate dat die interkorrelering tussen die tellings van die 16-PF en dié van die BMV ook besondere ondersteunende bewyse oor die konstrukgeldigheid van die BMV gelewer het. Hierdie bevindings is in ooreenstemming met dié van Miner (1978) met betrekking tot die interkorrelasies tussen die totale MSCS-telling en die skale van Ghiselli, se SDI, Gough Adjective Check List en die MyersBriggs Type Indicator.

Opsommenderwys blyk dit uit hierdie studie dat die interkorrelasies tussen die tellings van die BMV, die takseersentrum en die 16-PF besondere ondersteunende bewyse oor die konstrukgeldigheid van die BMV aan die lig bring. Menslikehulpbronbestuurders in organisasies kan dus die BMV gebruik om die werwing, keuring, ontwikkeling en loopbaanbeplanning van bestuurders met bestuurspotensiaal op ' $n$ meer wetenskaplike grondslag te plaas.

Voordat die BMV egter met vertroue as ' $n$ tegniek in menslikehulpbronbestuur in organisasies gebruik kan word, behoort die hertoetsbetroubaarheid en die konstrukgeldigheid daarvan verder ondersoek te word. In hierdie verband behoort die koppeling van bestuursmotivering met ander bestuursrelevante veranderlikes soos bestuursdoeltreffendheid, werksbetrokkenheid (Du Toit, 1989), tydoriëntasie (Louw \& Raubenheimer, 1990), die gesosialiseerde magsmotief (McClelland, 1975) en transformasionele leierskap (Bass, 1994) meer lig op die geldigheid van die rolteorie van bestuursmotivering te werp.

\section{VERWYSINGS}

Augustyn, J.C.D. \& Van Wyk, A.J. (1988). Die SestienPersoonlikheidsfaktorvraelys as hulpmiddel by die takseersentrum. Tydskrif vir Bedryfsielkunde. 14(2), 25-2.7.

Bartol, K.M. \& Martin, D.C. (1987). Managerial motivation among MBA students: A longitudinal assessment. Journal of Occupational Psychology, 60, 1-12.

Bass, B.M. (1994). Transformational leadership critical for South Africa. Human Resource Management, 10(1), 10-13.

Berman, F.E. \& Miner, J.B. (1985). Motivation to manage at the top executive level: A test of the hierarchic role-motivation theory. Personnel Psychology, 38,377-391.

Britz, P.J. (1987). Die geldigheid van bestuursbeoordeling-sentrums in die meting van bestuurspotensiaal en -sukses. Stellenbosch: Referaat gelewer tydens takseersentrum kongres, 29-30 April.

Cattell, R.B.; Eber, H.W. \& Tatsuoka, M.M. (1980). Handbook for the Sixteen Personality Factor Questionnaire (16 PF). 3rd ed. Champaign, Illinois: Institute for Personality and Ability Testing.

Coetsee, L.D. (1973). ' $n$ Biografiese en psigologiese profiel van ' $n$ aantal Suid-Afrikaanse bestuurders. Pretoria: Ongepubliseerde doktorale proefskrif. Potchefstroomse Universiteit vir Christelike Hoër Onderwys.

Coetsee, L.D. (1976). Suksesvolle bestuurders: 'n Profiel gebaseer op vier studies. Suid-Afrikaanse Sielkundige, 6(1), 9-17.

Crowne, D.P. \& Marlowe, D. (1960). A new scale of social desirability independent of psychopathology. Journal of Consulting Psychology, 24(4), 349-354.

De Bod, A.D. \& Slivinsky, L.W. (1983). Personality correlates of managerial talent: a cross-cultural comparison. Perspektiewe in die Bedryfsielkunde, 9(3), 11-36.

Du Toit, J. (1989). ' $n$ Bedryfsielkundige ondersoek na die verband tussen werksbetrokkenheid, organisasiebetrokkenheid en werksprestasie. Stellenbosch: Ongepubliseerde magistertesis, Universiteit van Stellenbosch.

Engelbrecht, A.S. (1989). Die rol van bestuursmotivering in bestuurspotensiaal, bestuursdoeltreffendheid en bestuurstevredenheid. Stellenbosch: Doktorale proefskrif, Universiteit van Stellenbosch.

Engelbrecht, A.S. (1991). Die ontwikkeling van die bestuursmotiveringsvraelys (BMV). Tydskrif vir Bedryfsielkunde, 17(2), 7-13.

Engelbrecht, A.S. \& De Jager, L.C. (1991). Die betroubaarheid en faktorstruktuur van die aangepaste meervoudige keuseformaat van die Miner Sentence Completion Scale (MSCS). Tydskrif vir Bedryfsielkunde, 17(2), 18-2.2.

Krug, S.E. (1983). Interpreting 16-PF profile patterns. Champaign, Illinois: Institute for Personality and Ability Testing, Inc.

Louw, J.W. \& Raubenheimer, I. van W. (1990). Die verband tussen tydoriëntasie, diepte-oriëntasie en lokus van kontrole. Tydskrif vir Bedryfsielkunde, 16(3), 11-15.

Maas, F. (1980). Die persoonlikheidsteorie van Caltell. Pretoria: RGN

Madge, E.M. \& Du Toit, L.B.H. (1982). ' $n$ Samevatting van die bestaande kennis in verband met die primêre persoonlikheidsfaktore wat deur die Persoonlikheidsvraelys vir kinders: (PVK), die Hoërskool-Persoonlikheidsvraelys (HSPV) en die SestienPersoonlikheidsfaktorvraelys (16-PF) gemeet word. Pretoria: RGN.

McClelland, D.C. (1975). Power: the inner experience. New York: Irvington-Wiley.

McClelland, D.C. (1987). Human motivation. New York: Cambridge University Press.

Miner, J.B. (1977). Motivation to manage: a ten-year update on the "Studies in Management Education" research. Atlanta, Georgia: Organizational Measurement Systems Press.

Miner, J.B. (1978). Twenty years of research on role-motivation theory of managerial effectiveness. Personnel Psychology, 31, 739-760.

Miner, J.B. (1992). Industrial-Organizational Psychology. New York: McGraw-Hill.

Spangenberg, H. (1990). Assessing managerial competence. Cape Town: Juta \& Co.

Stahl, M.J. (1986). Managerial and technical motivation. New York: Preager Publishers.

Yukl, G.A. (1994). Leadership in organizations. Englewrood Cliffs, New Jersey: Prentice-Hall. 